\title{
Technical aspects of the reconstruction of historic gardens
}

\author{
ALBERT FEKETE* ${ }^{*}$, MÁTÉ SÁROSPATAKI and SZABOLCS VAJDA
}

Department of Garden Art and Landscape Design, Institute of Landscape Architecture, Urban Planning and Garden Art, Hungarian University of Agriculture and Life Sciences, Hungary

\section{ORIGINAL RESEARCH PAPER}

Received: September 24, 2021 - Accepted: October 28, 2021

Published online: November 19, 2021

(c) 2021 The Author(s)

\section{ABSTRACT}

Built elements and structures are a prominent component of our historic gardens, both in terms of function and artistic composition and garden scenery. The surveys of historic garden structures are important research tasks, which also underpins and validates restoration work.

In most cases, the neglected state of historic gardens and sites and the unavailable archival materials do not allow an authentic restoration of historic gardens to their original state. Nevertheless, there is a real need to reconstruct our historic gardens, based not only on historical authenticity but also on a systematic reinterpretation of the relationship between society and landscape.

The objective of this article is to present a general methodology for renewal of historic gardens through examples of specific garden reconstructions. The case studies are the authors' own design works, which demonstrate the application of different design approaches, highlighting details of the reconstruction of specific built garden elements.

\section{KEYWORDS}

garden heritage, historic structure, renewal, landscape

\section{INTRODUCTION}

Landscape architecture has come a long way since the turn of the millennium: through the works realised, the artistic concepts and the far-sighted visions it has been integrated into the

\footnotetext{
*Corresponding author. E-mail: Fekete.Albert@uni-mate.hu
} 
group of engineering professions that feel responsible for shaping and actively working for the built environment. Once again, it has moved closer to the architecture from which it derived from, combining a technical, engineering approach with an ecological vision and an awareness towards the living and natural environment. Landscape architecture has become an independent discipline, dominant in contemporary Hungarian landscape and urban design, and in the field of heritage conservation it can also be designated as an independent discipline.

The environmental challenges of the last years, the problems of the liveability of settlements, the conscious management of water, have undoubtedly contributed to self-identification and professional recognition of landscape architecture, increasing the value of the work of landscape architects done with a comprehensive, cross-professional environmental approach.

The expansion of landscape architecture in Hungary is also due to the accession to the European Union, since after 2005 there have been several international charters, conventions, guidelines and initiatives, for the implementation of which a substantial financial support from EU funds was available, helping the realisation of local projects. Landscape architecture, both in Hungary and around the world, is fundamental and increasingly crucial to everyday life, both in terms of climate adaptation efforts and in terms of preserving health and social well-being.

Thanks to opening towards the general public, the technical content of landscape architecture, an engineering approach that considers the "garden" with all its components as an integrated whole, is becoming more familiar and accepted among practitioners of related disciplines as well as the lay public. The contemporary definitions of garden, landscape and landscape architecture (Csemez, 1996; Jámbor, 2009; IFLA Europe, 2021) also make it clear that, although the selection, location, ecological and aesthetic composition of plants is a basic requirement in the design of green spaces and open spaces, it by no means in itself covers the overall subject matter of the profession. The built, structural elements of the garden (paths, pavements, walkways, stairs, retaining walls, fences, water pools, fountains, sports fields, playground equipment, pergolas, arbours, pavilions, information systems and other outdoor structures) have been as important a component of our landscapes and gardens as the natural elements from the very beginning. The design, renovation and maintenance of these technical components have been and still are an integral part of the landscape architecture profession, and this is particularly true when it comes to the renewal of our historic gardens. Historic gardens are strongly linked to several disciplines and scientific fields, but their technical aspects are emphasised because of their structures and their special characteristic in urban layout and the landscape, resulting from their former estate system.

\section{OBJECTIVES}

The main objective of the article is to present some specific types of general historic garden restoration methodologies in the context of case studies. The examples focus on technical solutions that implement the different design approaches required by the actual situation. Through the technical and structural solutions, either traditional or innovative, used for restoration or renovation, the garden structures regain their central role in the garden composition and their intended use, while maintaining their historical authenticity.

The article presents design methods dealing with historical authenticity of the gardens, recognising in the same time the important role of new user's needs from point of view of the 
economical sustainability. The purpose is to investigate how high quality garden design is applicable in different historic environments.

\section{MATERIALS}

The historic garden is a protected institution. The historic garden was first defined by the Florence Charter as a category of monuments in 1981. According to this, the historical garden is "an architectural and horticultural composition of interest to the public from the historical and artistic point of view. As such, it is to be considered a monument." (ICOMOS MNB, 2002) This definition is still considered to be the basic formulation of gardening research and the historical garden category. Besides, the place of historic gardens in landscape architecture and the protection of monuments has become somewhat revalued. While in 1972 the first agreement of the UN Educational, Scientific and Cultural Organization in Paris for the protection of cultural and natural heritage barely contained landscape and gardening features (GC UNESCO, 1972), the World Heritage Council in Santa Fe in 1992 extended the concepts of "monuments" and "monument sites" to landscape categories (UNESCO, 1992).

Regarding the legal background of heritage protection in Hungary, the first law dealing with the issue of historic gardens was the Act on Monument Protection in 1997 (CXL, 1997). The Act on Heritage Protection adopted in 2001 - similarly to the 1997 Act - also classifies historic gardens as specific objects of monument protection (LXIV, 2001).

The central dilemma of historic landscape renewals are the right definition and restoration of the most important and characteristic time and style-layers of the site. Only through the historical authenticity, through a sensitive, site-specific design intervention can the cultural value and the essence of the site be preserved and represented (Fekete and Kollányi, 2019). A diverse set of international perspectives from established theories in landscape design (Steenbergen-Reh, 1996; Cosgrove, 1997; The NT, 2001; Hobhouse, 2002; Quest-Ritson, 2003; Balogh, 2006; BardócziDér, 2010; Fekete, 2008; Palang, 2012; Ingram, 2015; Bardóczi, 2015; van den Brink et al., 2017), environmental philosophy (Waks, 2001; Olin, 2008), structural engineering, geography, environmental history, psychology and sociology (Cullen, 1971; Lynch, 1974; Burns-Kahn, 2005; Sárospataki, 2014a; Eplényi, 2015; Zelenák, 2018), are acting together to create new, integrated restoration strategies including strong social, technical and ecological values as well.

The renewal of historic gardens used to be more and more actual in the Eastern and Central European Region in the last two decades, especially some technical aspects regarding to the design, execution and maintenance of built features, as components of historic gardens and sites.

Many early descriptions (Temple, 1685; Halfpenny, 1750; Chambers, 1757; Loudon, 1832; Székely, 1871), individual works (Dávid, 1987; Kresta, 2008; Fekete 2011) or comprehensive researches (B. Nagy, 1973; Biró, 1943; von Buttlar, 1989; Stirling, 1995; Fatsar, 2008; Firnigl, 2011; Jámbor, 2006; Sárospataki, 2013, 2014b; 2019), based on historical exploration and on-site investigation focus on defining the inner and outer visual connections and functional elements of the castle gardens, as well as their compositional significance. The scientific results show that the majority of the eye-catchers - the most important elements that define the main outlook directions and visual axes of the landscape composition - are represented by these, predominantly built constructions (gloriettes, pavilions, obeliscs, temples, chapels, etc.) with strong technical characteristics. Similarly, the most important functional elements of the gardens were 
represented as far back as the 15-16th centuries, even in the Renaissance gardens, by built features (trellis, pergolas, pavilions, fences, bridges, etc.)

Landscape architecture is an applied science. Taking into consideration the main guidelines on the preparation of scientific papers in art and garden history, the design and renewal principles of presented technical features are based on preliminary historical studies and researches.

Therefore, this article is not a detailed description of a single project realised, but the introduction of multiple features restored in different gardens of varied historic value. This is the best way to prove that the restoration of technical components is one of the important tools of the reconstruction of historic garden layouts and designed landscapes. The case studies demonstrate and focus on the restoration of the technical elements/built features, so that the solutions applied to meet the specific needs of clients and users are based on the research results, and also comply with the historical authenticity.

On the other hand, the present study draws on several researches that investigate the history, compositional elements and renovation opportunities of castle gardens in the Carpathian Basin. These studies of garden history clearly support the importance of the architectural and technical elements of gardens for art history across the ages. The built elements of gardens play an important role in garden history regarding both function and composition. As an example, based on an analysis of one hundred Transylvanian castle gardens, Table 1 summarises the technical elements of gardens that also play a role in organising visual composition in garden or even larger-scale landscape design.

The relevant heritage conservation principles (Balogh, 2006; Fekete, 2016), based on the available facts and information related to a site, being used in case of renewal of technical features as well, can be ordered according to Fekete and Kollányi (2019) in the following three categories:

\section{Garden renovation}

A garden reconstruction based on the historical sources available, the heritage features of the site which are possible to identify, and the stylistic elements and analogies of a specific period. The park is renovated with a distinct application of the stylistic elements of the period most relevant to the site, and with additional functions to meet the actual demands.

\section{Garden regeneration}

The park that has lost its historic features to a great extent is reconstructed on the basis of historical sources and analogies available. The solutions applied integrate the features of the relevant historical period into contemporary contexts. This approach includes the opportunity of creating a contemporary work of art.

\section{Garden restoration}

Garden reconstruction based on the exploration of historical sources, the archaeological surveys, the use of preserved garden features, etc. Based on the preserved historic features and the available historical sources, it is possible to restore a part or the whole of the garden so that it will be greatly identical to the original design. 
Table 1. Garden features with strong technical background in some Transylvanian castle gardens (Source: Fekete, 2019)

\begin{tabular}{|c|c|c|c|}
\hline & Manor garden & Owner (family) & Type of the eye-catcher \\
\hline 1 & Abafája (Apalina, MS) & Huszár & $\begin{array}{l}\text { 1.1. Statue of The Three Graces } \\
\text { 1.2. Fountain, ornamental pool } \\
\text { 1.3. Boathouse }\end{array}$ \\
\hline 2 & Árkos (Arcus, CV) & Szentkereszti & $\begin{array}{l}\text { 2.1. Fountain, ornamental pool } \\
\text { 2.2. Grotto } \\
\text { 2.3. Artificial gorge } \\
\text { 2.4. Cascade and canal }\end{array}$ \\
\hline 3 & Árokalja (Arcalia, BN) & Bethlen & $\begin{array}{l}\text { 3.1. Garland urn } \\
\text { 3.2. Tomb }\end{array}$ \\
\hline 4 & Bethlen (Beclean, BN) & Bethlen & 4.1. Winged genius (does not exist) \\
\hline 5 & Bonchida (Bontida, CJ) & Bánffy & $\begin{array}{l}\text { 5.1. Hunter's lodge } \\
\text { 5.2. Artificial cave } \\
\text { 5.3. Gloriette } \\
\text { 5.4. Statues } \\
\text { 5.5. Obelisks } \\
\text { 5.6. Fountain } \\
\text { 5.7. Grotto (do not exist) }\end{array}$ \\
\hline 6 & Bonyha (Bahnea, MS) & Bethlen & $\begin{array}{l}\text { 6.1. Stone lion statues } \\
\text { 6.2. Grotto (does not exist) }\end{array}$ \\
\hline 7 & Cege (Taga, CJ) & Wass Jenő & $\begin{array}{l}\text { 7.1. Statues (only pedestals and } \\
\text { fragments exist) } \\
\text { 7.2. Ornamental pool of a fountain }\end{array}$ \\
\hline 8 & Fehéregyháza (Albesti, MS) & Haller & 8.1. Gloriette \\
\hline 9 & Csákigorbó (Garbau, SJ) & Haller-Jósika & $\begin{array}{l}\text { 9.1. Baroque wellhouse } \\
\text { 9.2. Chapel } \\
\text { 9.3. Statues (only pedestals and } \\
\text { fragments exist) }\end{array}$ \\
\hline 10 & Gernyeszeg (Gornesti, MS) & Teleki & $\begin{array}{l}\text { 10.1. Mythological statues (Juno, } \\
\text { Neptune, Pan, Venus, Ceres, } \\
\text { Bacchus and Ganymedes) } \\
\text { 10.2. Statues of dwarfs } \\
\text { 10.3. Garland urn } \\
\text { 10.4. Spout-well } \\
\text { 10.5. Obelisk }\end{array}$ \\
\hline 11 & $\begin{array}{l}\text { Görgényszentimre (Gurghiu, } \\
\text { MS) }\end{array}$ & Rákóczi-Bornemisza & $\begin{array}{l}\text { 11.1. Statues of Sphinxes } \\
\text { 11.2. Sculpture of wrestling bears } \\
\text { 11.3. Spout-well } \\
\text { 11.4. Elisabeth table and memorial } \\
\text { stone } \\
\text { 11.5. War memorial } \\
\text { 11.6. Gazebo } \\
\text { 11.7. Fragments of other statues }\end{array}$ \\
\hline 12 & Gyalu (Gilau, CJ) & Rákóczi-Barcsay & $\begin{array}{l}\text { 12.1. Spout-well, basin } \\
\text { (continued) }\end{array}$ \\
\hline
\end{tabular}

(continued) 
Table 1. Continued

\begin{tabular}{|c|c|c|c|}
\hline & Manor garden & Owner (family) & Type of the eye-catcher \\
\hline 13 & Gyulafehérvár (Alba Iulia, AB) & $\begin{array}{c}\text { Római Katolikus Püspöki } \\
\text { Palota }\end{array}$ & 13.1. Carved stone urns and vases \\
\hline 14 & Hadad (Hodod, SM) & Wesselényi-Degenfeld & $\begin{array}{l}\text { 14.1. Flight of stone stairs with } \\
\text { ornamental urns }\end{array}$ \\
\hline 15 & Kendilóna (Luna de Jos, CJ) & Teleki & $\begin{array}{l}\text { 15.1. Watchtower } \\
\text { 15.2. Gloriette (does not exist) }\end{array}$ \\
\hline 16 & Keresd (Cris, MS) & Bethlen & $\begin{array}{l}\text { 16.1. Family crypt } \\
\text { 16.2. Renaissance carved stone } \\
\text { bench (does not exist) }\end{array}$ \\
\hline 17 & Kerlés (Chirales, BN) & Bethlen & $\begin{array}{c}\text { 17.1. Gazebo } \\
\text { 17.2. Fountain, ornamental pool } \\
\text { 17.3. Grotto } \\
\text { 17.4. Stone statues (none of them } \\
\text { exist) }\end{array}$ \\
\hline 18 & Kutyfalva (Cuci, MS) & Degenfeld & 18.1. Water tower \\
\hline 19 & $\begin{array}{l}\text { Küküllővár (Cetatea de Balta, } \\
\qquad \mathrm{AB})\end{array}$ & Bethlen & $\begin{array}{l}\text { 19.1. Statue and coat of arms of } \\
\text { Bethlen }\end{array}$ \\
\hline 20 & Magyarfenes (Vlaha, CJ) & Jósika & $\begin{array}{l}\text { 20.1. Gloriette (does not exist) } \\
\text { 20.2. Grotto (does not exist) } \\
\text { 20.3. Cascade (does not exist) }\end{array}$ \\
\hline 21 & Marosnémeti (Mintia, HD) & Gyulay & 21.1. Fountain, ornamental pool \\
\hline 22 & $\begin{array}{c}\text { Marosvécs (Brancovenesti, } \\
\text { MS) }\end{array}$ & Kemény & $\begin{array}{l}\text { 22.1. Aladár Kuncz memorial table } \\
\text { 22.2. Albert Wass memorial place } \\
\text { 22.3. Tombs of János Kemény and } \\
\text { Auguszta Kemény } \\
\text { 22.4. Tomb of Baron György } \\
\text { Kemény }\end{array}$ \\
\hline 23 & Nagykároly (Carei, SM) & Károlyi & $\begin{array}{l}\text { 23.1. Statue of St Florian } \\
\text { 23.2. Fountain, ornamental pool } \\
\text { 23.3. Water tower }\end{array}$ \\
\hline 24 & Pusztakamarás (Camarasu, CJ) & Kemény & $\begin{array}{l}\text { 24.1. Stone table } \\
\text { 24.2. Memorial stone }\end{array}$ \\
\hline 25 & Piski (Simeria, HD) & Ocskay-Fáy & $\begin{array}{l}\text { 25.1. Kazinczy memorial table } \\
\text { 25.2. Spout-well, artificial gorge } \\
\text { 25.3. Fragments of statues }\end{array}$ \\
\hline 26 & Sárpatak (Glodeni, MS) & Teleki & 26.1. Statues of lions \\
\hline 27 & Soborsin (Savarsin, AR) & Nádasdy-Forray & $\begin{array}{l}\text { 27.1. Gazebo } \\
\text { 27.2. Chapel }\end{array}$ \\
\hline 28 & Szászfelek (Avrig, SB) & Bruckenthal & $\begin{array}{l}\text { 28.1. Fountain, ornamental pool } \\
\text { 28.2. Flight of stone stairs, terrace, } \\
\text { balustrade } \\
\text { 28.3. Spout-well } \\
\text { 28.4. Hermitage } \\
\text { 28.5. Fake ruins } \\
\text { 28.6. Fragments of statues }\end{array}$ \\
\hline
\end{tabular}

(continued) 
Table 1. Continued

\begin{tabular}{|c|c|c|c|}
\hline & Manor garden & Owner (family) & Type of the eye-catcher \\
\hline 29 & Székelyhíd (Sacueni, BH) & Stubenberg & $\begin{array}{l}\text { 29.1. Ornamental pool with a } \\
\text { sculpture } \\
\text { 29.2. Terrace balustrade } \\
\text { 29.3. Fountain, ornamental pool }\end{array}$ \\
\hline 30 & $\begin{array}{c}\text { Székelyszenterzsébet (Elisei, } \\
\text { HR) }\end{array}$ & Kemény & $\begin{array}{l}\text { 30.1. Ornamental pools } \\
\text { 30.2. Pavilion (none of them exist) }\end{array}$ \\
\hline 31 & Szentbenedek (Manastirea, CJ) & Kornis & $\begin{array}{l}\text { 31.1. Statues of unicorns } \\
\text { 31.2. Baroque wellhouse }\end{array}$ \\
\hline 32 & Válaszút (Rascruci, CJ) & Bánffy & $\begin{array}{l}\text { 32.1. Bird house (does not exist) } \\
\text { 32.2. Fountain, ornamental pool }\end{array}$ \\
\hline 33 & Váralmás (Almasu, SJ) & Csáky & $\begin{array}{l}\text { 33.1. Fragments of statues } \\
\text { 33.2. Fragments of an ornamental } \\
\text { pool }\end{array}$ \\
\hline 34 & Zabola (Zabala, CV) & Mikes & $\begin{array}{l}\text { 34.1. Pedestals of statues } \\
\text { 34.2. Flights of stone stairs with } \\
\text { stone columns }\end{array}$ \\
\hline 35 & Zsibó (Jibou, SJ) & Wesselényi & $\begin{array}{l}\text { 35.1. Statues of lions (2) } \\
\text { 35.2. Fountain, ornamental pool } \\
\text { 35.3. Family crypt } \\
\text { 35.4. Gazebo (does not exist) }\end{array}$ \\
\hline
\end{tabular}

The article presents examples on the first two of these design approaches (Garden renovation and Garden regeneration). The first example is the reconstruction of the retaining wall system, garden pavilion and wooden bridge of the Kálnoky Castle Garden in Miklósvár (Miclosoara, $\mathrm{RO}$ ), the second is the reconstruction of the built elements (water pool, fence, pergola) of the herb garden in the Benedictine Abbey of Pannonhalma.

\section{DISCUSSIONS AND RESULTS}

\section{Technical aspects of the Kálnoky castle garden renewal from Miklósvár (Miclosoara, RO)}

The Kálnoky Castle in Miklósvár (Miclosoara, RO) was built in Renaissance style in the 17th century and has preserved its Late Renaissance character till nowadays. The building is listed, managed by the former owner Kálnoky family. The 14 ha manor park is a historic garden, and, according to archival sources from 17th and 18th centuries, its northern part was a garden with typical Renaissance structures (INv, 2014). Not just written documents, but still existing landforms has also confirmed the existence and location of the former fishpond, placed at the lowest part of the garden.

Parterred herb gardens, usually octagonal shingled pavilions, fishponds and wooden bridges are characteristic elements of the Transylvanian garden art in the 16-18 centuries (Stirling, 1995; Fekete 2008). The renovation design managed the reconstruction of the concerned technical garden features accordingly (Fig. 1). 

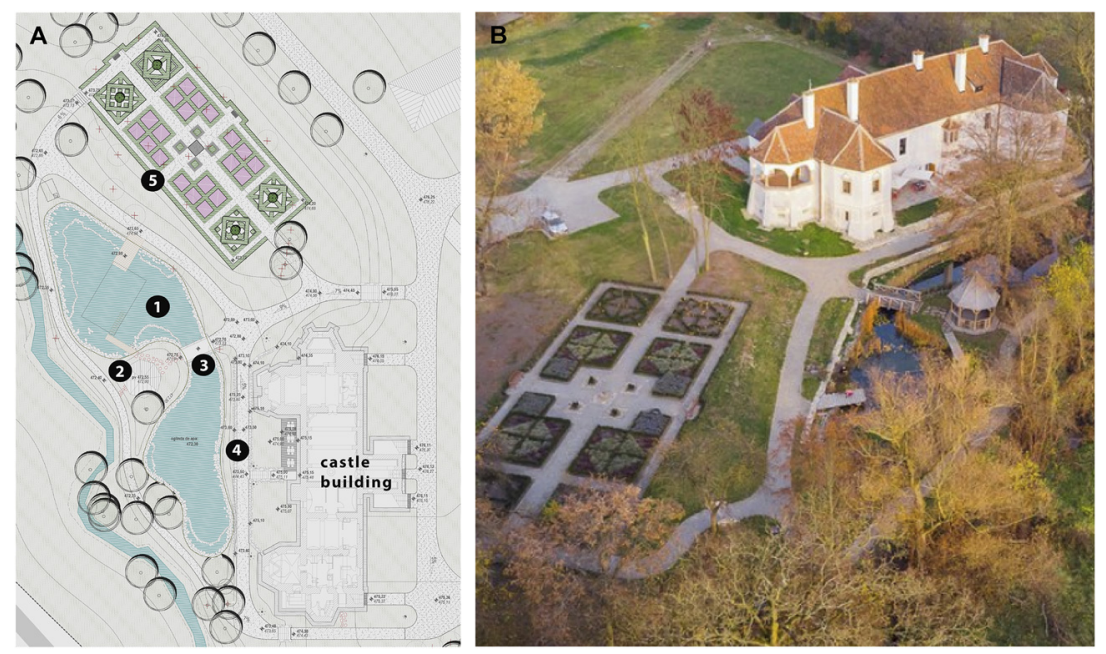

Fig. 1. a. Detail of the garden plan with typical Late Renaissance restored garden features: fishpond (1), garden pavilion (2), wooden bridge (3), retaining walls (4) and herb garden (5); b. Aerial photo of the restored garden section

(Source: Plan - Fekete et al., 2015; Photo - Kálnoky Foundation, 2018)

The pond was connected with the castle building with a double RETAINING WALL, which - during the centuries - became covered by earth. During the site surveys, the landforms of the garden showed clearly the line of the retaining walls. Its original location and technical and constructional details were identified through archaeological survey. The results of the archaeological excavations served as the most authentic source for the redesign and reconstruction of the retaining wall (Figs 2 and 3).

When the construction plans for the restoration of the retaining walls were approved, the authority responsible for historic monuments stipulated that the original drystone walls should be replaced by reinforced concrete retaining walls more resistant to soil erosion, with a natural stone covering. Although the renovated retaining walls were built exactly where the original retaining walls were found by archaeologists, and according to the original dimensions, the new technology (reinforced concrete) means that they cannot be considered as restoration, only as reconstruction.
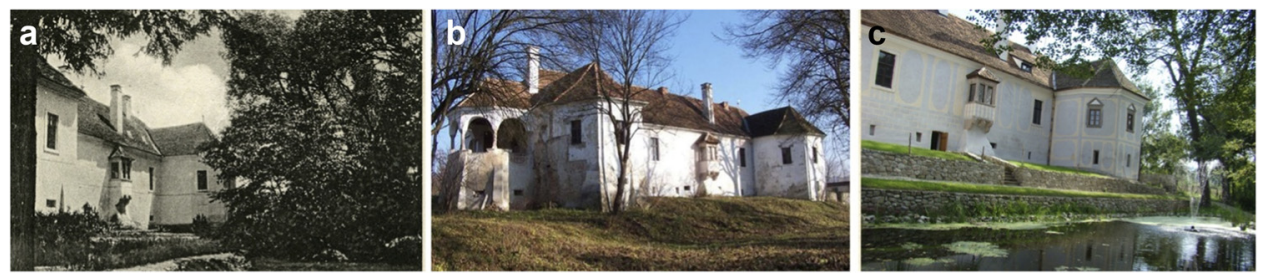

Fig. 2. The North facade of the Kálnoky castle, the retaining walls and the pond in 1912 (a), 2014 (b) and after the reconstruction in 2016 (c)

(Source: Fekete et al. (2015) (a, b); Photo: Fekete Albert, 2017 (c)) 

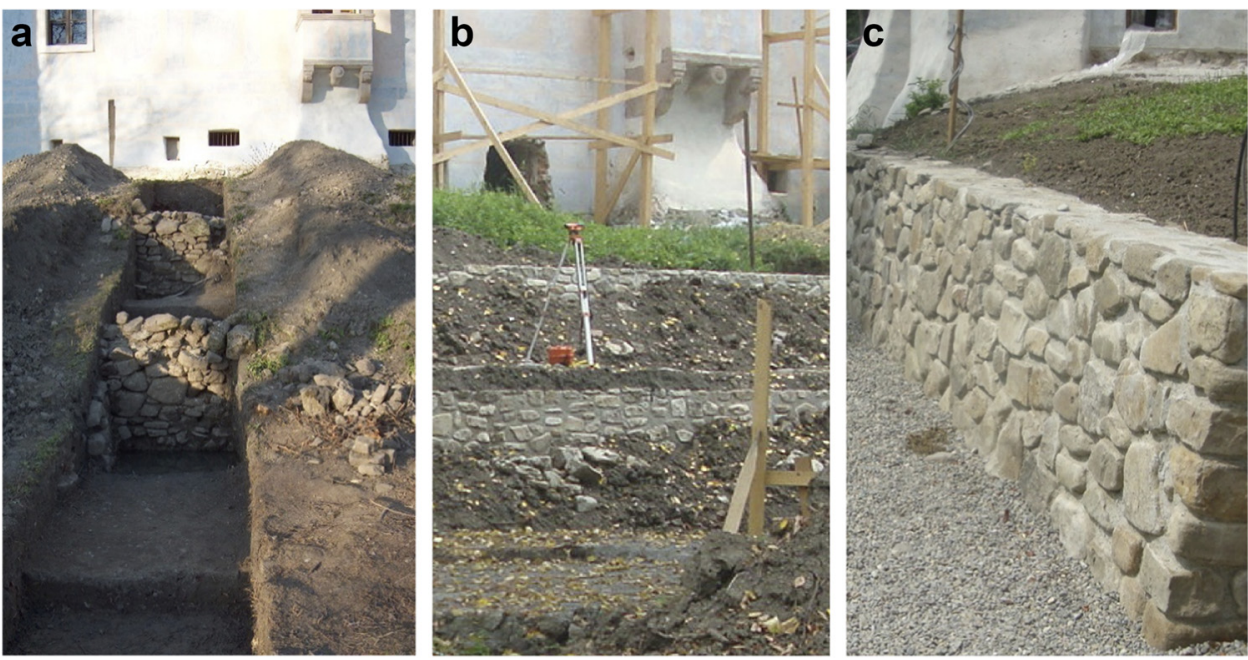

Fig. 3. Retaining walls in Kálnoky castle garden, Miklósvár, discovered through archaeological excavation, 2014 (a); the retaining walls during the reconstruction, 2015 (b) and after the reconstruction, 2016 (c)

(Source: Fekete Albert, 2014 (a), 2016 (b, c))

The missing authentic written sources of the PAVILION from the Kálnoky estate made possible a redesign based on historical descriptions of pavilions from other Hungarian gardens of that age, and also based on the investigation of the characteristic technical details of the 17th century's Transylvanian architecture (Fig. 4).

Roofed garden structures are mentioned several times in the 16th and 17th century garden descriptions of the Carpathian Basin, as follows:

- Csetnek (Štítnik, SK) - 1636: “. . s shingled gazebo in a tiny vegetable garden ...”;

- Terjékfalva (Teriakovce, SK) - 1712: four-column gazebo ("Hortus unus culinae deserviens in cuius meditullio est filagoria lignea in quattuor columnis ligneis");

- Lengyelfalva (Košická Polianka, SK) - 1672: gazebo in the vegetable garden;

- Felsőmicsinye (Horná Mičiná, SK) - end of the 17th century: in an orchard ("Sub castelli cinctura immediate Hortus, puteum, fructifens arbores et filegoriam habens");

- Vágbeszterce (Považská Bystrica, SK) - 1689: gazebo with wall paintings;

- Tiszaújhely (Nove Szelo, UKR) - undated

- Munkács (Munkacevo, UKR) - undated:“... two gazebos, one of which has a round layout and gallery-like appearance...";

- Zétény (Zatín, SK) - 1672: gazebo in a flower garden;

- Csáktornya (Čakovec, HR) - 1692: triple-decked gazebo in Pál Újhelyi’s garden.

- Vajdahunyad (Hunedoara, HD) - undated

- Búzásbocsárd (Bucerdea Vinoasa, $\mathrm{AB}$ ) - undated: gazebo built in a vineyard (it is extremely rare to have a gazebo in a vineyard!);

- Szilágycsehi (Cehul Silvaniei, SJ) - undated: gazebo built in a flower garden;

- Görgényszentimre (Gurghiu, MS) - 1652 

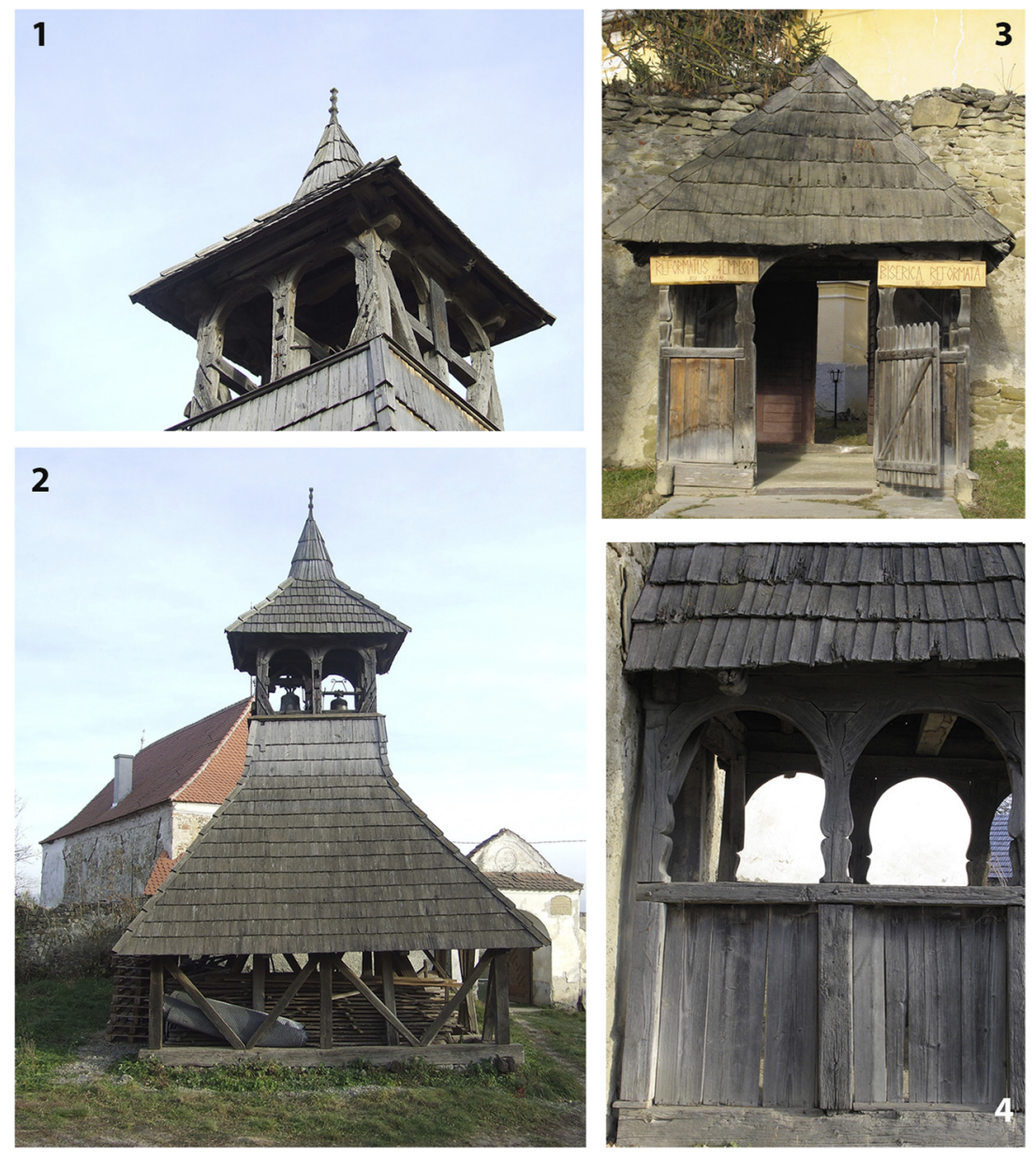

Fig. 4. 17th-century Transylvanian belfries, which structural elements and technical solutions served as an example for the renewal of the garden gazebo and wooden bridge. No. 1 and no. 2: the belfry in Kálnok; no. 3 and 4: the church entrance in Torja

(Source: Fekete et al., 2015)

- Fogaras (Fagaras, BV) - 1637

- Uzdiszentpéter (Sanpetru de Campie, MS) - 1679

- Gerend (Grindeni, CJ) - 1653

- The 1646 inventory about the manor garden of Péter Gyerömonostori Kemény in Magyarbükkös includes a reference to a complex of gazebos. The gazebos here are not exclusively stand alone: "The inventory of the Magyarbükös (Lower Fehér County) manor house refers to a linked gazebo and trellis, where a summer house was built in the trellis garden.”

Ede Thoroczkai Wigand also highlights the importance of gazebos in Transylvanian gardens of the age, describing gazebos that he calls "turriculum voluptarium" as the most characteristic 
elements of Late Renaissance gardens. Based upon the descriptions reviewed, we can conclude that gazebos were mostly round or regular polygonal (tetragonal, hexagonal or octagonal) wooden structures, occasionally with multiple decks. Some were built on a stone foundation, shingled and ornamented with a tin flag or ball on the top, sometimes also with carvings and paintings. Gazebos were open, semi-open or closed at the sides.

Comparing the conclusions of the various descriptions against the one from Miklósvár, it was possible to design a gazebo that fits into the setting, and serves as an accented visual feature at the pond (Fig. 5).

The same procedure was applied in the case of the rebuilding of the WOODEN BRIDGE, leading from the Northern castle façade to the garden pavilion located on the small peninsula of the pond (Fig. 6).

\section{Technical aspects of the renewal of the herb garden and arboretum of the archabbey in Pannonhalma}

The project proposed the renovation of two sections of the archabbey gardens distinct in their character and use. Originally, the 12-hectare arboretum on the northern slope of St Martin's Hill was used as a vineyard and orchard. According to the archives, the garden construction and plantation of ornamental species started in the 1820s. The Lavender Garden and the related Herb Garden to the east from the Arboretum was also founded at this time.

Actions throughout the Arboretum were directly targeted at the renovation of the surroundings of buildings and garden structures. The new open spaces created in the garden in the course of the renovations restored the visual links of the structures that were earlier surrounded by thick vegetation and difficult to access, and also provided new perspectives for the use of the Baroque pavilion (Fig. 7).

In addition to the renovations, building upon the character of the garden and also in response to growing visitor demands, a new leisure ground for groups was provided at the upper part of the sledge slope, which provides an ideal location with its unique views and favorable land forms. The oval surface with benches aligned radially may accommodate nearly 40 persons. Thus it is also suitable for short presentations, so that the audience is sitting with their back towards the valley. The slope towards the hilltop serves a pleasant backdrop for the presenter, while the opening of the sledge slope provides a wonderful vista into the opposite direction (Fig. 8).

Traditionally, the Herb Gardens always had a leading role in the economic sustainability of different monastic orders. Accordingly, the renewal of the environment of the horticultural buildings recall the atmosphere of traditional farmyards. The courtyard was fenced by low stone walls made by gray limestone coverage and coping from Balatonszőlös (Fig. 9).

The herb garden reflects this approach as well. The simple, geometrical layout organised in a composition thanks to the planting beds and the static water surface of the garden pool are all applied to strengthen the feeling of functionalism (Fig. 10).

Nevertheless, regarding the functional structures of the garden (pool, pergola, fence) the design, the layout and the material use present a contemporary character that are also capable to cope with the load of tourism. The built structures and outdoor furniture are all geometric: block-like benches, while the hard surfacing applies the same minor cobble stones and gravel that are general throughout the abbey (Fig. 11). 


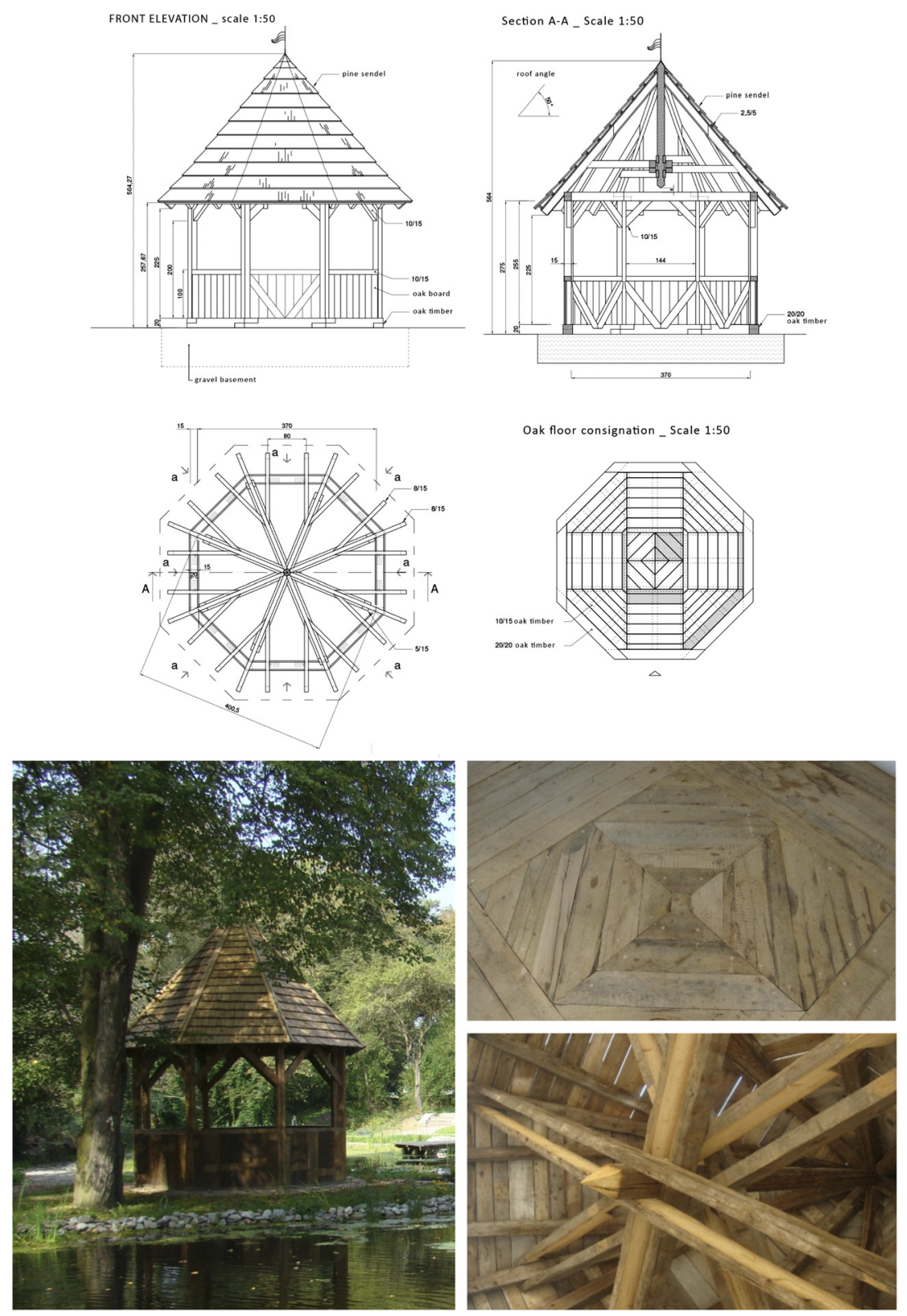

Fig. 5. Plans, view and details of technical detail realisation of the pavilion in Kálnoky Castle Garden from Miklósvár, restored according to historical descriptions and analogical examples (Source: Plan - Fekete et al., 2015; Photo - Fekete Albert, 2017) 


\section{WOODEN BRIDGE_Scale 1:25}
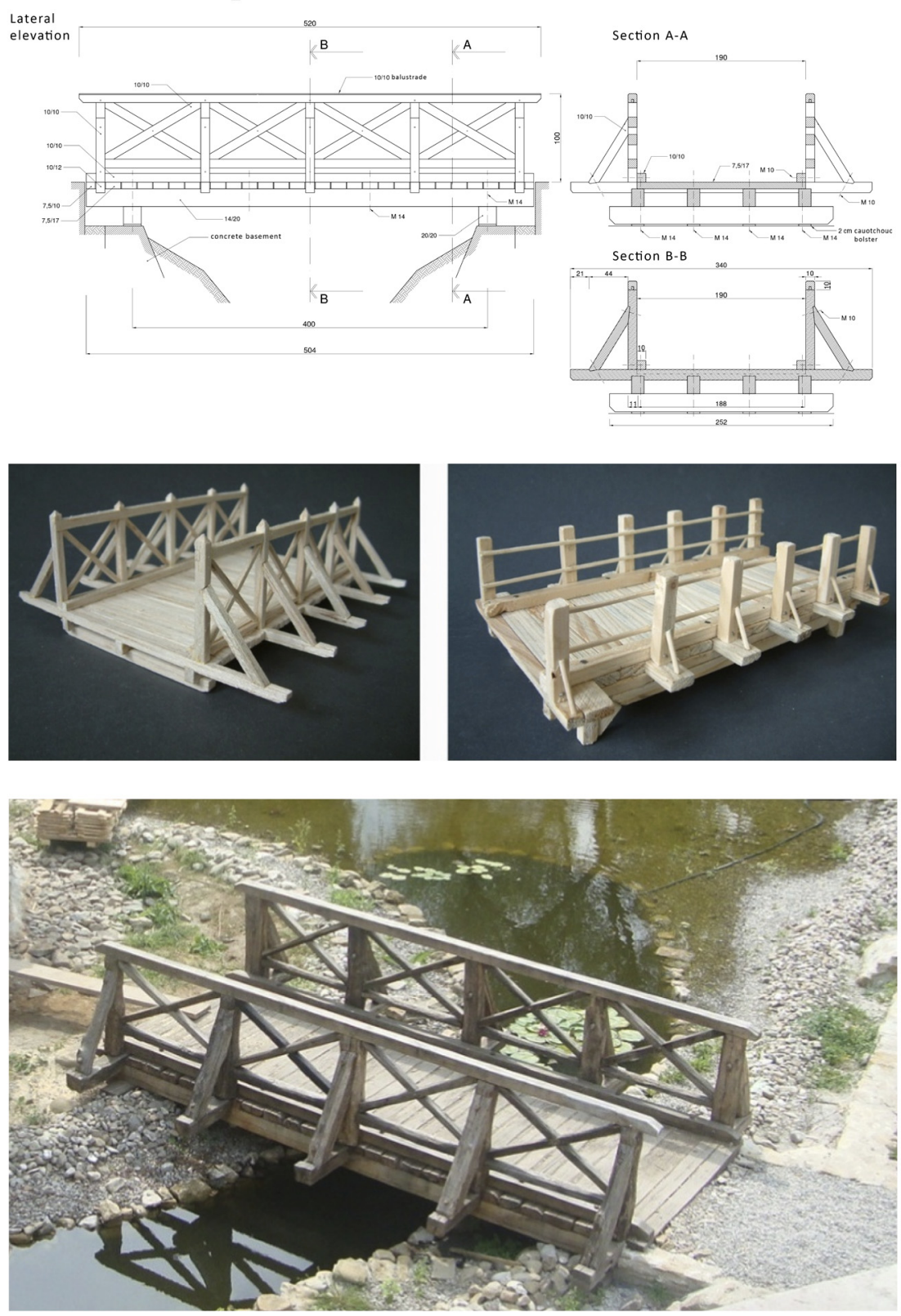

Fig. 6. Technical plans, maquettes and the bridge constructed (Source: Plan - Fekete et al., 2015; Photo - Fekete Albert, 2016) 


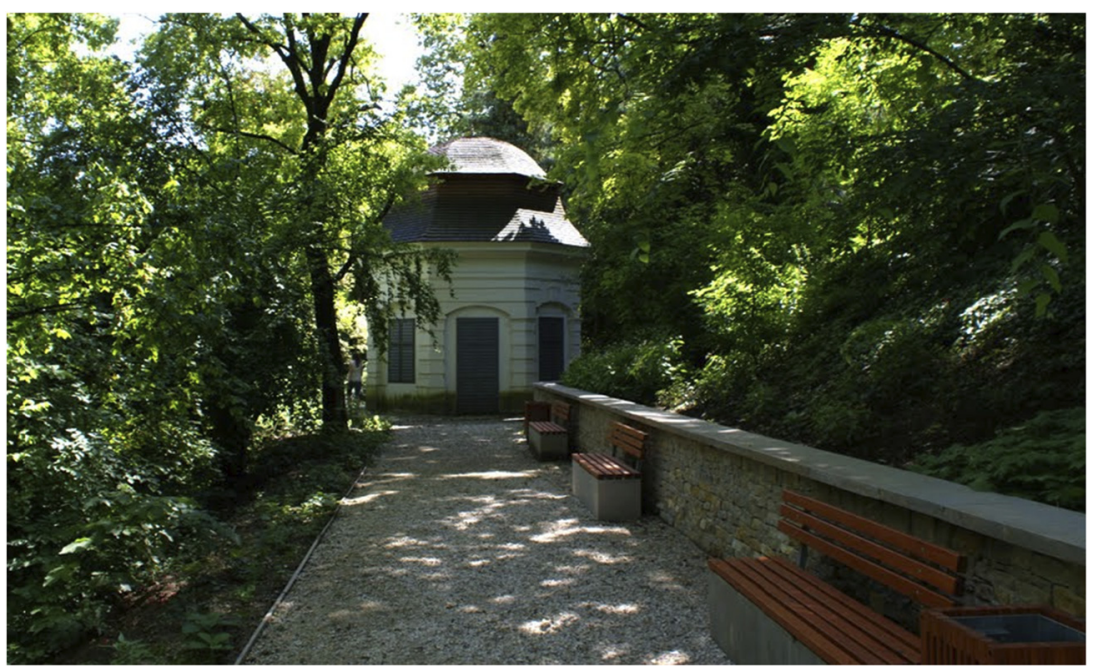

Fig. 7. The refitted surrounding of the Baroque pavilion in the Arboretum with a leisure ground and a petanque court established at the site of the former bowling alley

(Source - Photo: Fekete Albert, 2015)

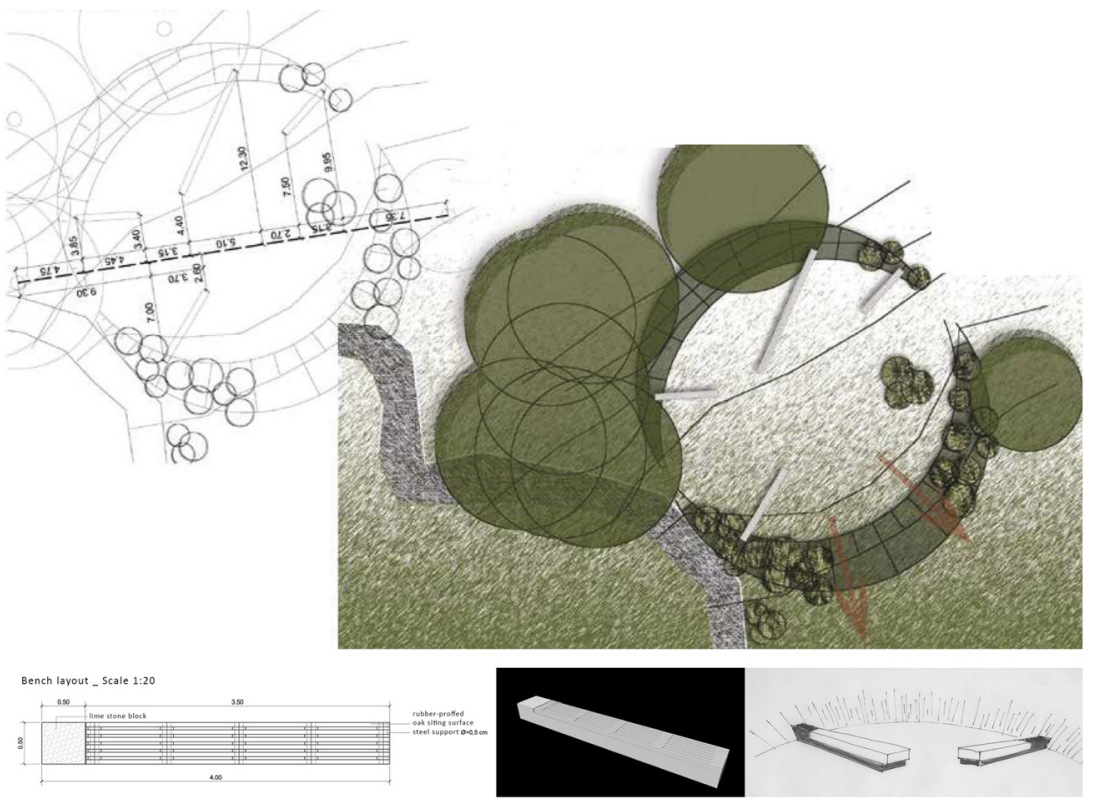

Fig. 8. Siting and structural design of the benches of the leisure ground/viewing platform on the top of the sledge slope of the Arboretum

(Source: Fekete et al., 2012) 
FENCE AND RETAINING WALL SECTION _ Scale 1:20
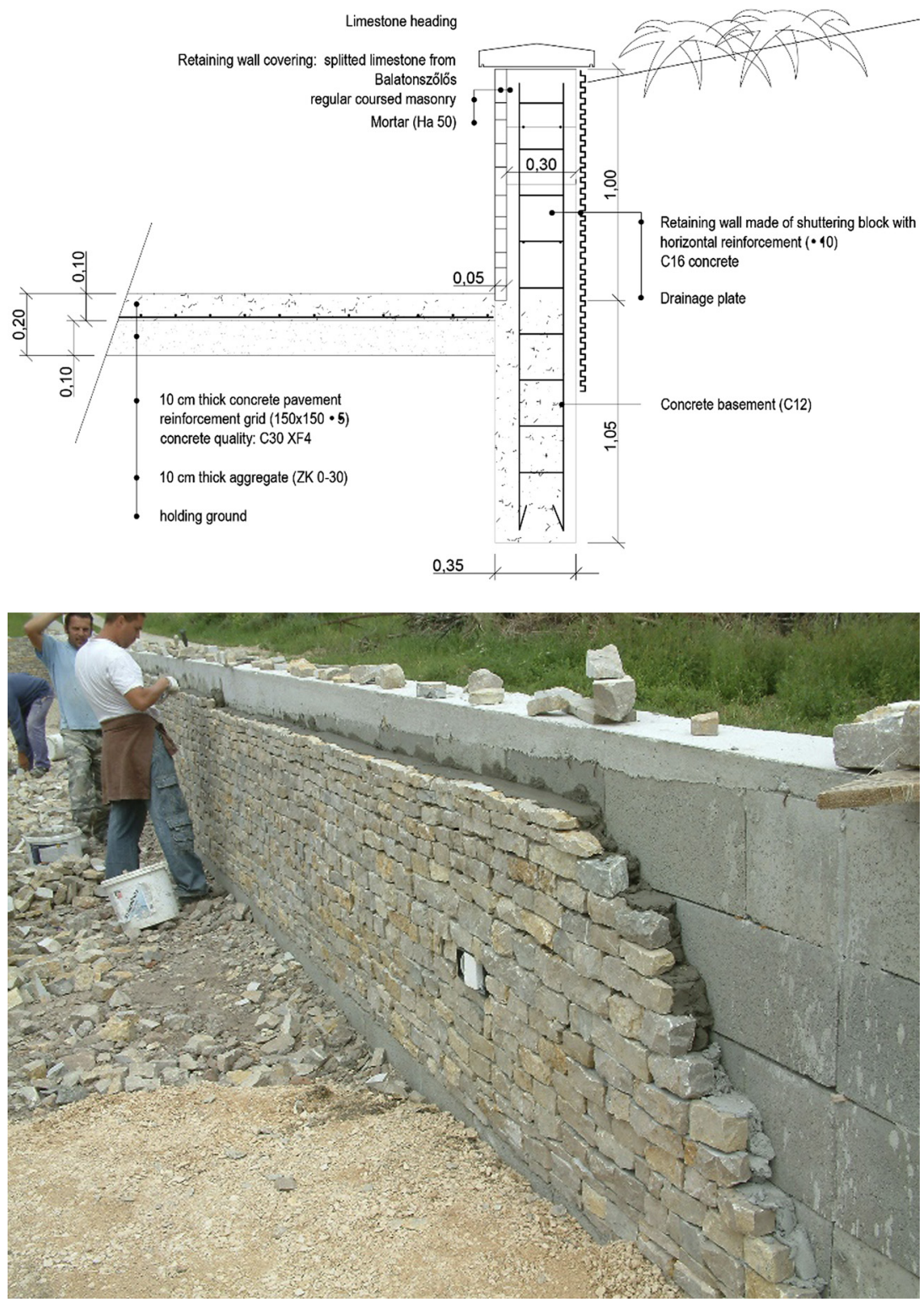

Fig. 9. Technical plan of the herb garden fence/retaining wall and the state of the limestone paving in the course of construction (Source: Fekete et al., 2012) 


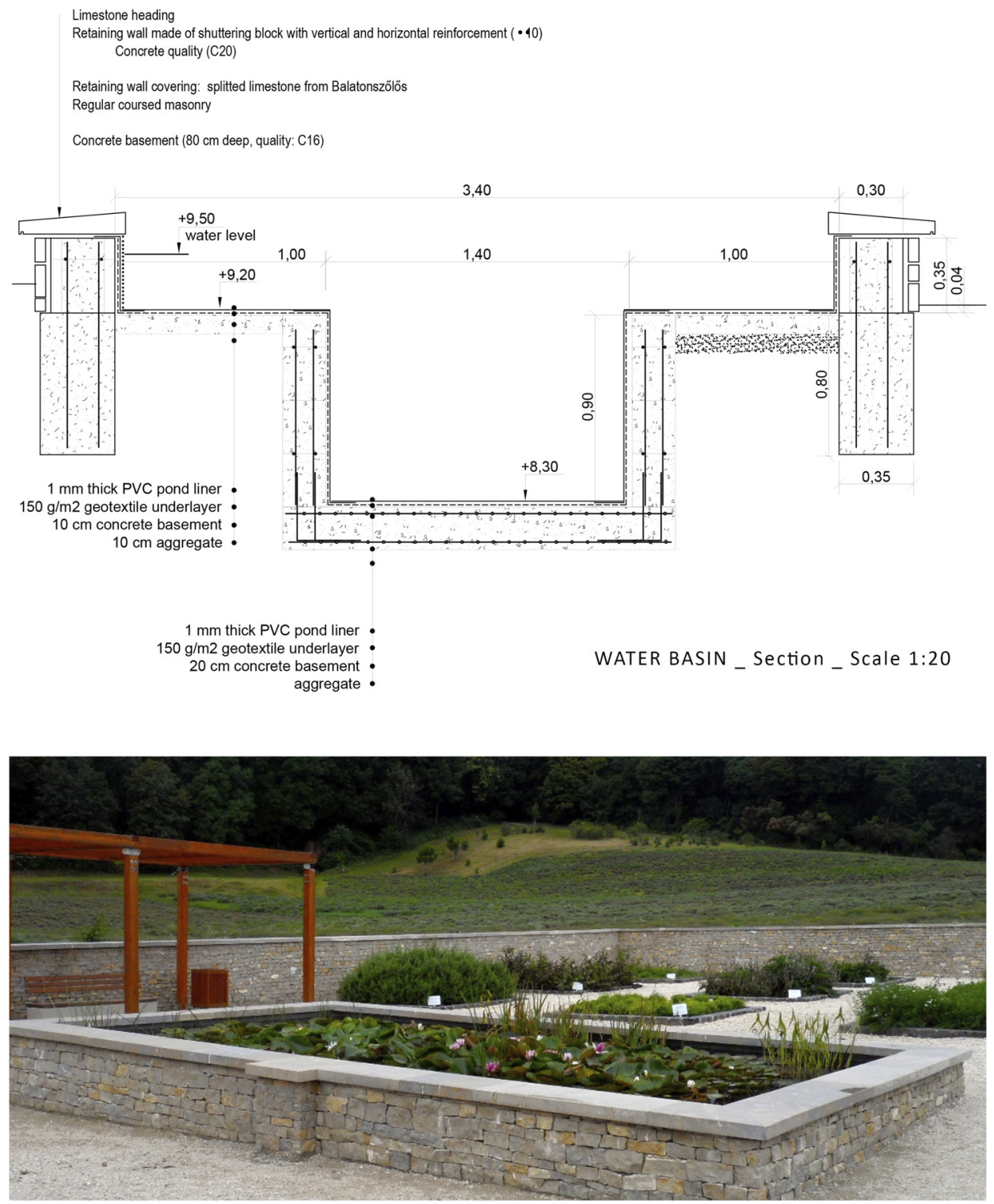

Fig. 10. Technical plan and photo of the ornamental pool

(Source: Design: Fekete et al., 2012, Photo: Vajda Szabolcs, 2014)

Authentic sources of the herb garden regarding its size, placement or layout, which could have served for a full restoration, were not available. That is why the garden features were regenerated based on analogies, using adequate technical solutions and a minimalistic design. That is why we called the approach "garden regeneration." 

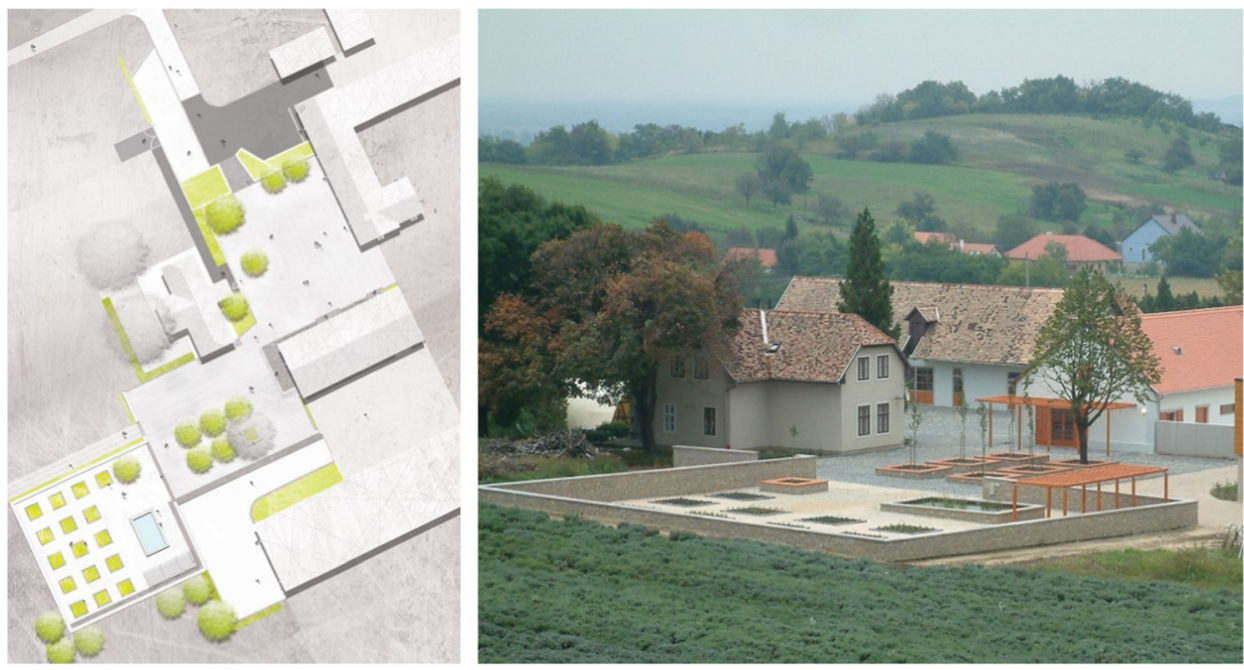

Fig. 11. Garden regeneration design for the herb garden and its surroundings and a photo of the renewed site

(Source: Design: Fekete et al., 2012, Photo: Vajda Szabolcs, 2014)

\section{CONCLUSIONS}

Renewal of historic sites always generates discussions. The main goal during a garden or open space renewal is that the renovation must show authentic solutions and must preserve the character and the message of the site; all redesigned technical features must reflect the original functions and show sustainable solutions.

Due to the missing archival sources, garden restoration is a rarely applicable option in EasternEurope. The current conditions of historic gardens and the unavailability of historical evidence (often still uncatalogued, inaccessible, incomplete) in most cases do not allow for a restoration of the original situations, and is possible to restore on the basis of the features preserved and the data available on the actual conditions.

Through the examples introduced, we intend to present and support some contemporary renewal theories, strategies and approaches in historic garden renewal, and to formulate new approaches, principles, ways and proposals on historic garden restoration and planning, with regard to special, technical aspects of redesigning the gardens.

The presented overviews are not comprehensive: due to the limits on length, and in order to focus on the topics (functional, technical and infrastructural features) of the article we included only some relevant details of the projects.

Despite the difficulties to explore their past, from the survey of actual conditions, it is possible to establish that our garden structures and very functional technical feature, through its historic character represent an important part of our cultural heritage. 


\section{REFERENCES}

Balogh, P.I. (2006). Szabadtér-tervezés történeti környezetben. 4D Tájépitészeti és Kertmüvészeti Folyóirat, 2006(3): 38-44.

Bardóczi, S. (Ed.) (2015). 2015: Tájodüsszeia. Katalógus a magyar tájépitész szakma 2010-2015 közötti legfontosabb alkotásaiból (EN: 2015: landscape Odyssey - landscape architecture in Hungary, the most significant projects and artworks 2010-2015). Hungarian Association of Landscape Architects, Budapest.

Bardóczi, S. and Dér, A. (Eds.) (2010). 2010: Tájodüsszeia. Katalógus a magyar tájépítész szakma 2000-2010 közötti legfontosabb alkotásaiból (EN: 2010: landscape Odyssey - catalogue of the most important landscape architectural projects in Hungary 2000-2010). Hungarian Association of Landscape Architects, Budapest.

Biró, J. (1943). Erdélyi kastélyok, Új Idők Irodalmi Intézet (Singer és Wolfner) Budapest.

Burns, C.J. and Kahn, A. (Eds.) (2005). Site matters - design concepts, histories and strategies. Routledge, London/New York.

Buttlar, A. von (1999). Az Angolkert. Köln. Magyar kiadás, hasonmás címmel, Budapest.

B. Nagy, M. (1973). Várak, kastélyok, udvarházak, ahogy a régiek látták. Kriterion Kiadó, Bukarest.

Chambers, W. (1757). The drawings, buildings, furniture, habits, machines and utensils of the Chinese. R. Dodsley, London.

Cosgrove, D.E. (1997). Cultural landscapes. In: Unwin, T. (Ed.), A European geography. Longman, London, pp. $65-81$.

Csemez, A. (1996). Tájtervezés - tájrendezés. Mezőgazda Kiadó, Budapest.

Cullen, G. (1971). The concise townscape. The Architectural Press, London.

Dávid, F. (1987). A gödöllói kastély kutatása. Kézirat. Research documentation 1987/88. p. 25.

Eplényi, A. (2015). „Garden-fragments”. Garden design and historical landscape heritage in Calata region.

Transsylvania Nostra Journal. Year IX, 33rd Issue: 20-32.

Fatsar, K. (2008). Magyarországi barokk kertmüvészet. Helikon Kiadó, Budapest.

Fekete, A. (2008). Lugaskert, filegória, halastó. Korunk, Period 3, 19(7).

Fekete, A. (2011). Garden culture and approaches to landscape from Gábor Bethlen to József Teleki II. In:

Kovács, K.G. (szerk.), Studies in the history of early modern Transylvania. Atlantic Research and Publications (ARP), pp. 396-419.

Fekete, A. (2016). Layered landscape design. In: Bauer, P., Collender, M., Jakob, L., Ketterer Bonnelame, P., Petschek, P., Siegrist, D., and Tschumi, C. (Eds.), Bridging the Gap. Conference Proceedings. Series of the Institute for Landscape and Open Space, HSR Hochschule für Technik Rapperswil No. 14. ECLAS Conference 2016, Rapperswil, Switzerland.

Fekete, A. (2019). Komponált látványok. Történeti kertek és tájak helyreállitása. Szent István Egyetem Tájépítészeti és Településtervezési Kar, Budapest.

Fekete, A. and Kollányi, L. (2019). Research-based design approaches in historic garden renovation. Land, 8(12): 192.

Fekete, A., Vajda, Sz., and Szilágyi, K. (2012). A Pannonhalmi Bencés Fóapátság Arborétumának és Gyógynövénykertjének megújitási terve (The landscape renewal plan of the arboretum and herb garden from the archabbey of Pannonhalma, Hungary). Landscape Architectural Documentation Prepared for the Pannonhalma Archabbey, Budapest, Hungary. 
Fekete, A., Rudd, M., Sárospataki, M., and Weiszer, Á. (2015). A Miklósvári Kálnoky Kastélykert Megújítási Terve (The landscape renewal plan of the Kálnoky castle garden from Miklósvár). Landscape Architectural Documentation Prepared for the Kálnoky Foundation, Miklósvár (Miclosoara), Romania.

Firnigl, A. (2011). Sculptures in the gardens - from the historical ages to the "neo-embarrassing" trends. Publication of the First International Conference "Horticulture and Landscape Architecture in Transylvania" Agriculture and Environment Supplement, 28-40.

Halfpenny, W. (1750). New designs for Chinese temples. Robt. Sayer, London.

Hobhouse, P. (2002). The story of gardening. Dorling Kindersley Limited, London.

Ingram, M. (2015). Material transformations: urban art and environmental justice. In: Hourdequin, M. and Havlick, D.G. (Eds.), Restoring layered landscapes. Chapter 12. University Press, Oxford.

Jámbor, I. (2006). Egy elveszett illúzió. Festői kertek a 18. század első felében. 4D Tájépítészeti és Kertmüvészeti Folyóirat, 1. sz: 9-17.

Jámbor, I. (2009). Bevezetés a kertépitészet történetébe. FVM Vidékfejlesztési, Képzési és Szaktanácsadási Intézet, Budapest.

Kresta, E. (2008). Nature by Design - Lush gardens and spacious parks characterize the garden kingdom of Dessau-Wörlitz. The Atlantic Times, May 2008.

Loudon, J.C. (1832). Gardener's magazine. London.

Lynch, K. (1974). Site planning, 2nd ed/4th pr. MIT, Cambridge.

Olin, L. (2008). Placemaking. The Monacelli Press, New York.

Palang, H. (2012). The practices of Landscape Heritage. Zoll+ Österreichische Schriftenreihe für Landschaft und Freiraum. Österreichische Gesellschaft für historische Garten, Wien, Austria, Nummer 21/ Dezember (2012) Jahrgang 22: 87-94.

Quest-Ritson, Ch. (2003). The English garden. A Social history. Penguin Books, Suffolk.

Sárospataki, M. (2013). Role of representative woody plants in the spatial composition of dendrological gardens. Folia Oecologica, 40(1): 141-144.

Sárospataki, M. (2014a). Vallató Bath and Mofetta. In: Jakab Cs. and Márton L. A. (Eds.), Épités/building. La Biennale di Venezia. Alföldi Nyomda Zrt, Debrecen, pp. 86-87.

Sárospataki, M. (2014b). Dendrológiai kertek a 19. századi magyarországi kertépitészetben (PhD dissertation) Budapest: Corvinus University of Budapest.

Steenbergen, C. and Reh, W. (1996). Architecture and landscape. The design experiment of the great European gardens and landscapes. Prestel Verlag, Munich.

Stirling, J. (1995). Magyar reneszánsz kertmüvészet a XVI-XVII. században. Enciklopédia Kiadó, Budapest.

Székely, F. (1871). Görgényszentimre leírása (monographia). Kézirat a Görgényszentimrei Református Egyházközség irattárában.

Temple, W. (1685). Upon the gardens of epicurus. In: Sir William temple upon the gardens of epicurus, with other XVII. Century garden essays, 1908. Chatto and Windus. p. 54. London.

The National Trust (NT). (2001). Rooted in history. Studies in garden conservation. The National Tust Enterprise Ltd, London.

Van den Brink, A., Bruns, D., Tobi, H., and Bell, S. (2017). Research in landscape architecture. Methods and methodology. Routledge, New York.

Waks, L.J. (2001). Donald Schön's philosophy of design and design education. International Journal of Technology and Design Education, 11(1): 37-51.

Zelenák, F. (2018). Tájépitészet és környezetpszichológia. A szabadtéri minőség és a helykötödés összefüggései budapesti lakótelepeken. Doktori értekezés. SZIE Tájépítészeti és Tájökológiai Doktori iskola, Budapest. 


\section{SOURCES}

ICOMOS MNB. (2002). A történeti kertek kartája (Firenzei Karta). Müemlékvédelmi dokumentumok gyüjteménye. ICOMOS Magyar Nemzeti Bizottság, Budapest.

GC UNESCO. (1972). The General Conference of the United Nations Educational, Scientific and Cultural Organization meeting in Paris from 17 October to 21 November 1972, Convention Concerning the Protection of the World Cultural and Natural Heritage. In: http://whc.unesco.org/en/conventiontext/.

UNESCO. (1992). United Nations Educational, Scientific and Cultural Organization Convention concerning the protection of the World Cultural and Natural Heritage, World Heritage Committee, Sixteenth session, Santa Fe, United States of America, 7-14 December 1992. In: http://whc.unesco.org/ archive/repcom92.htm.

CXL. (1997). 1997. évi CXL. törvény a müemlékvédelemről.

LXIV. (2001). 2001. évi LXIV. törvény a kulturális örökség védelméröl.

IFLA. (2021). IFLA (International Federation of Landscape Architects) definition about the profession of LANDSCAPE ARCHITECT. https://iflaeurope.eu/.

INV. (2014). Inventarul castelului din Micloşoara întocmit în anul 1698, lb. maghiară; Arhiva fam. Kálnoky. Fasc. 31. In: Fehér J. (Ed.) Castelul Kálnoky din Micloşoara (jud. Covasna), studiu de istoria artei, Sfantu Gheorghe.

Open Access. This is an open-access article distributed under the terms of the Creative Commons Attribution 4.0 International License (https://creativecommons.org/licenses/by/4.0/), which permits unrestricted use, distribution, and reproduction in any medium, provided the original author and source are credited, a link to the CC License is provided, and changes - if any - are indicated. (SID_1) 